\title{
THE EFFECT OF INCREASING LEVELS OF INSOLUBLE DIETARY FIBRE ON THE ESTABLISHMENT AND PERSISTENCE Of Oesophagostomum dentatum IN PIGS
}

\author{
PETKEVIČIUS S.***, NANSEN P.*, BACH KNUDSEN K.E.*** \& SKJØTH F.****
}

\section{Summary :}

This investigation compared the effect of diets with increasing content of insoluble dietary fibre (DF) on the establishment and persistence of Oesophagostomum dentatum in growing pigs. Twenty-eight worm-free pigs, from a specific pathogen-free farm were randomly divided to four groups of seven animals. The animals were assigned to the following $\operatorname{diets}$ : $\operatorname{diet} A$, barley flour plus protein mixture $(70 \%$ : $30 \%)$; diet B, barley flour, oat husk meal plus protein mixłure $(65 \%: 7 \%: 28 \%)$; diet $\mathrm{C}$, barley flour, oat husk meal plus protein mixture $160 \%$ : $14 \%$ : $26 \%$ ) and diet D, barley flour, oat husk meal plus protein mixture $155 \%$ : $21 \%: 24 \%$ ). The diets were formulated to provide increasing content of DF but constant levels of digestible protein per feeding unit for pigs. All pigs were experimentally inoculated with 6,000 infective $O$. dentatum larvae and followed coprologically for 11 weeks post infection, whereafter they were slaughtered. The experimental diets influenced the mean transit time and the metabolism in the large intestine significantly. Diets C and D, with highest content of insoluble DF, provided favourable conditions for establishment of $O$. dentatum, but diets $A$ and $B$ led to a significant lower worm numbers and fecundity.

KEY WORDS : Oesophagostomum dentatum, dietary fibre, pigs, nutrition MOTS CLÉS : Oesophagostomum dentatum, régime en fibres, porc, nutrition

\section{INTRODUCTION}

I $\mathrm{n}$ recent studies on experimentally infected indoor pigs ( Petkevičius et al., 1995, 1997 a; Bjørn et al., 1996) it was shown that diets, differing mainly in content of carbohydrates not digested by endogenous

\footnotetext{
* Danish Centre for Experimental Parasitology, Department of Veterinary Microbiology, Royal Veterinary and Agricultural University, Ridebanevej 3, DK-1870 Frederiksberg C, Denmark.

** Lithuanian Veterinary Institute, LT- 4230 Kaišiadorys, Lithuania. *** Department of Animal Nutrition and Physiology, Danish Institute of Agricultural Sciences, Research Centre Foulum, P.O. Box 50, DK8830 Tjele, Denmark.

**** Department of Biometry and Informatics, Danish Institute of Agricultural Sciences, Research Centre Foulum, P.O. Box 23, DK-8830 Tjele, Denmark.

Correspondence: S. Petkevičius.

Tel: +45-35-28-27-92 - Fax: +45-35-28-27-74 - E-mail: spe@kvl.dk
}

Résumé : EFFET de RÉGIMEs CONTENANT DES TAUX CROISSANTS DE FIBRES ALIMENTAIRES INSOLUBLES DANS L'INSTALLATION ET LA PERSISTANCE D' OESOPHAGOSTOMUM DENTATUM CHEZ LE PORC

Cette étude compare l'effet de régimes contenant des quantités croissantes de fibres alimentaires insolubles sur l'installation et la persistance d'Oesophagostomum dentatum chez le porc en période de croissance. 28 porcs sains en provenance d'une ferme non pathogène ont été divisés en quatre groupes randomisés de sept animaux et soumis aux régimes suivants: régime $A$, farine d'orge enrichie d'un mélange protéique $(70 \% / 30 \%)$; régime $B$, farine d'orge, balle d'avoine et mélange protéique (65\%/7\%/28 \%), régime $C$, farine d'orge, balle d'avoine et mélange protéique $160 \% / 14 \% / 26 \%$; ; et régime D, farine d'orge, balle d'avoine et mélange protéique $(55 \% / 21 \% / 24 \%)$. Les régimes ont été déterminés de manière à apporter un contenu croissant en fibres alimentaires insolubles, mais avec des niveaux constants de protéines assimilables dans chaque ration alimentaire. Tous les porcs ont été contaminés expérimentalement par 6000 larves infestantes $d ' O$. dentatum, et suivis sur le plan coprologique pendant 11 semaines après l'infestation, au terme desquelles ils ont été abattus.

Ces régimes expérimentaux ont influencé de manière significative la durée moyenne du transit et le métabolisme au sein du gros intestin. Les régimes $C$ et $D$, les plus riches en fibres alimentaires insolubles, créent des situations favorables à l'installation $d^{\prime} O$ dentatum, alors que les régimes $A$ et $B$ diminuent de manière significative le nombre et la fécondité des helminthes.

enzymes (oligosaccharides and non-starch polysaccharides (NSP)) led to significant differences in establishment, gut location and fecundity of Oesophagostomum dentatum. These findings correspond to observations (Von-Brand, 1979; Nesheim, 1984; Crompton, 1991), that growth and development of gastrointestinal parasites depends on type and amount of dietary carbohydrates. Moreover it is well established that polysaccharide composition and content of lignin plays an important role for the physico-chemical environment in the gut lumen and for microbial fermentation in the large intestine of pigs (e.g. Bach Knudsen et al., 1991, 1993; Johansen et al., 1997).

The present study was undertaken to investigate the effect of increasing concentration of insoluble dietary fibre $(\mathrm{DF}=\mathrm{NSP}+$ lignin $)$ on establishment and persistence of $O$. dentatum in experimental infected growing pigs. The four experimental diets consisted of a 
low DF diet based on barley flour plus a protein mixture and three diets with increasing levels of insoluble DF obtained by substitution of barley flour and part of the protein mixture with oat hull meal. Oat hull meal has a high concentration of insoluble DF components in the form of cellulose, non-cellulosic polysaccharides (NCP) and lignin (Bach Knudsen, 1998). We hypothesized that high levels of insoluble DF would improve conditions for establishment of gastrointestinal nematode infection.

\section{MATERIALS AND METHODS}

\section{EXPERIMENTAL DESIGN}

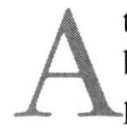

total of 28 Landrace/Yorkshire/Duroc crossbreed females were obtained from a specific were approximately 11-weeks-old on arrival and their average weight was $35 \mathrm{~kg}$ at the start of the experiment. Pigs were randomly divided into four groups of seven animals and each group was kept in a separate equally sized pen with solid floors. Pens were thoroughly disinfected and dried prior to introduction of the pigs and at regular intervals during the study period. Excreta was removed twice daily and pigs were kept without bedding. Experimental pigs had free access to water via drinking nipples.

Prior to the start of the experiment, parasite-free status of the pigs was confirmed by repeated faecal exami- nations. Pigs were kept for three weeks in pens prior to parasite inoculations to allow them to adapt to the environment and to the four experimental diets. Afterwards all pigs were inoculated by a stomach tube with a single dose of 6,000 infective larvae of $O$. dentatum strain isolated in 1983 (Roepstorff et al., 1987).

The four experimental diets were formulated on basis of barley flour, oat hull meal and protein concentrate (Table I). Diets were formulated with increasing levels of DF from $161 \mathrm{~g}$ to $228 \mathrm{~g}$ but constant levels of digestible protein (Just, 1971) per feeding units for pigs (FUp, Just, 1975) (Table I). Chromium oxide, as an insoluble marker, was added to the diets at a level of $2 \mathrm{~g}$ per $\mathrm{kg}$ feed for the last two weeks of the experiment. Pigs were fed twice daily with $12 \mathrm{hr}$ intervals with an amount adjusted to $2.1 \mathrm{FUp} / \mathrm{pig} / \mathrm{d}$ at $35 \mathrm{~kg}$ increasing to $2.9 \mathrm{FUp} / \mathrm{pig} / \mathrm{d}$ at week 11 .

Faecal samples were collected rectally every week for worm egg counts and for evaluation of faecal consistency. The last two weeks before slaughtering, samples of experimental diets and feed components were collected for chemical analysis. Throughout the experiment pigs were weighed every second week. All pigs were slaughtered at 11 weeks post-inoculation (p.i.).

\section{PARASITOLOGICAL TECHNIQUeS}

Faecal egg counts were monitored using a modified McMaster technique with a lower level of detection of 20 eggs $\mathrm{g}^{-1}$ (epg). At the end of the experiment, after an overnight fast, all animals were euthanised by $\mathrm{CO}_{2}$

\begin{tabular}{|c|c|c|c|c|c|c|c|c|}
\hline & \multicolumn{8}{|c|}{ Diet } \\
\hline & \multicolumn{2}{|c|}{$\underset{\text { B-70 } \%, \text { P-30 \% }}{\mathbf{A}}$} & \multicolumn{2}{|c|}{$\begin{array}{c}\mathbf{B} \\
\text { B-65 \%, O-7 \%, P-28 \% }\end{array}$} & \multicolumn{2}{|c|}{$\begin{array}{c}\mathbf{C} \\
\text { B-65 \%, O-14\%, P-26\% }\end{array}$} & \multicolumn{2}{|c|}{$\begin{array}{c}\text { D } \\
\text { B-55 \%, O-21 \%, P-24 \% }\end{array}$} \\
\hline Ash & 62 & & 61 & & 61 & & 60 & \\
\hline Protein $(\mathrm{N} \times 6.25)$ & 225 & & 205 & & 198 & & 195 & \\
\hline $\mathrm{HCl}$-fat & 39 & & 39 & & 39 & & 39 & \\
\hline Starch & 515 & & 443 & & 439 & & 406 & \\
\hline Cellulose & 25 & & 39 & & 49 & & 56 & \\
\hline NCP & 108 & (44) & 119 & $(40)$ & 130 & (41) & 137 & (41) \\
\hline Arabinose & 22 & (2) & 22 & (4) & 24 & (2) & 24 & (5) \\
\hline Xylose & 24 & (4) & 32 & (0) & 46 & (2) & 53 & (3) \\
\hline Mannose & 7 & (2) & 7 & (3) & 6 & (2) & 6 & (2) \\
\hline Galactose & 14 & (6) & 15 & (6) & 15 & (6) & 14 & (5) \\
\hline Glucose & 29 & (21) & 26 & (11) & 26 & (19) & 27 & (20) \\
\hline Uronic acids & 11 & (6) & 11 & (5) & 13 & (7) & 12 & (5) \\
\hline Total NSP & 133 & & 158 & & 179 & & 193 & \\
\hline Klason lignin & 28 & & 27 & & 33 & & 35 & \\
\hline Dietary fibre (DF) & 161 & & 185 & & 212 & & 228 & \\
\hline FUp & 1.28 & & 1.2 & & 1.12 & & 1.07 & \\
\hline Digestible protein/FUp & 126 & & 128 & & 128 & & 128 & \\
\hline
\end{tabular}

NSP, non starch polysaccharides; NCP, non-cellulosic polysaccharides; FUp, Feeding Units for pigs; ND, not determined. Values in parentheses are soluble NSP. B-barley flour; O-oat hull meal; P-protein mixture.

Table I. - Chemical composition ( $\mathrm{g}$ or FUp per kg Dry-Matter) of the experimental diets and the plant materials for diets. 
and exsanguinated. The entire small and large intestines were immediately removed and separated from mesenteries. From each pig the large intestine was divided into the caecum (Ce) and into four (Co1-0$20 \%$; Co2- 21-40 \%; Co3- 41-60\%; and Co4-5-61$100 \%)$ sections of colon and rectum. The content was weighed, $\mathrm{pH}$ measured and samples taken for detailed chemical analysis. Samples for chemical analysis were taken from distal small intestine ( $4 \mathrm{~m}$ ), caecum and the five colon sections. The samples are referred to as ileum (I), caecum (Ce) and colon 1-5 (Co 1-5). Because the amount of digesta in Co5 was limited and the sample missing from several pigs the Co5 samples were omitted from chemical analysis.

Oesophagostomum dentatum worms were collected from materials of the caecum, colon and rectum using a modified agar-gel method described by Slotved $e t$ al. (1996). Each section was cut and opened with a scissors and the content of the gut was washed into saline. Representative sub-samples of $20 \%$ were taken from the contents of each section. All agar-gel samples were incubated in saline for $24 \mathrm{hr}$. After harvesting, worms were transferred to screw capped plastic tubes, fixed and stored in iodine solution (1 part of iodine + 5 parts of potassium iodide +10 parts of distilled water). Samples were decolorized with 3\% thiosulphate solution and the worms subsequently counted. Developmental stages of $O$. dentatum were determined using the criteria of Goodey (1926). The sex of adults was noted.

\section{ANALYSES OF FEED INTESTINAL CONTENTS}

All analyses were performed in duplicate. Analysis of lactic acid (LA) and short chain fatty acids (SCFA) were performed on wet materials by the gas chromatographic method of Richardson et al. (1989) and chromic oxide $\left(\mathrm{Cr}_{2} \mathrm{O}_{3}\right)$ measured by the method of Schürch et al. (1950). The pH was also performed on wet materiales, while the other analyses were carried out on freeze-dried materials. The dry matter (DM) content of feed was determined by drying at $105^{\circ} \mathrm{C}$ to constant weight and of digesta materials by freeze-drying.

Protein $(\mathrm{N} \times 6.25)$ was determined by the Kjeldahl method using a Kjell-Foss 16,200 autoanalyser, ash in accordance to the Association of Official Analytical Chemists (1975), and fat (hydrochloric acid-fat) was extracted with diethyl ether after acid hydrolysis (Stoldt, 1952). The feeding units for pigs were estimated in vitro as described by Boisen \& Fernández (1998). Starch was analysed by an enzymatic method described by Bach Knudsen (1993) and total, soluble and insoluble NSP and their constituent sugars in plant materials and diets and total NSP in digesta were determined as alditol acetates by gas chromatography for neutral sugars and by the colorimetrical method for uronic acids using a modification of the Uppsala (Theander \& Åman, 1979; Theander \& Westerlund, 1986) and Englyst (Englyst et al., 1982) procedures as described by Bach Knudsen (1997).

Cellulose was calculated as:

cellulose $=\mathrm{NSP}_{\text {glucose }\left(12 \mathrm{~mol}^{-1}\right)}-\mathrm{NSP}_{\text {glucose }\left(2 \mathrm{~mol}^{-1}\right)}$,

non-cellulosic polysaccharides (NCP) were calculated as: $\mathrm{NCP}=($ arabinose + xylose + mannose + galactose + glucose + uronic acids)

and soluble NSP (S-NSP) as: S-NSP = Total-NSP - INSP,

where I-NSP are insoluble NSP.

Klason lignin was measured gravimetrically as the residue resistant to $12 \mathrm{~mol} 1^{-1} \mathrm{H}_{2} \mathrm{SO}_{4}$ (Theander \& Åman, 1979; Theander \& Westerlund, 1986).

\section{STATISTICAL ANALYSIS}

Faecal egg counts (epg) were recorded weekly until slaughter at 11 weeks p.i. Due to non-response data epg for $O$. dentatum are given only from week 3 to 11. The diet effects were analyzed by a multivariate analysis of variance (ANOVA) assuming that the transformed counts $\log _{10}(e p g+10)$ for each pig are multivariate normal with an unconstrained covariance common to all pigs and with mean $\mathrm{E}\left(\log _{10}(e p g+10)_{\mathrm{ij} k}\right)$ $=\alpha_{i}+\beta_{j}+\gamma_{i j}$, where $\alpha_{i}$ is the diet main effect, $\beta_{j}$ is the main effect of week, and $\gamma_{i j}$ represents the diet week interaction, index $k$ represents the pig.

Oesophagostomum dentatum worms were observed in sections $\mathrm{Ce}$ and $\mathrm{Co} 1$ to $\mathrm{Co} 5$, but data from sections $\mathrm{Co} 4$ and $\mathrm{CO} 5$ are combined. The diets are contrasted for each section and analyzed by means of a univariate ANOVA.

As an indication of the mean position of the O.dentatum worms along the large intestine, the average location of worms for each pig was calculated as:

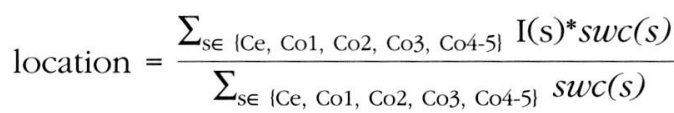

where $\mathrm{I}(\mathrm{Ce})=1, \ldots, \mathrm{I}(\mathrm{Co} 4-5)=5$ and $\operatorname{swc}(s)$ is the worm count in section $s$. The effect of diet on the average location was investigated by a univariate ANOVA. The effect of diet on the proportion of female O. dentatum worms was investigated by ANOVA on the arcsine transformed proportions.

For pigs with a positive female adult worm burden at week 11 , fecundity of $O$. dentatum female worms was estimated by dividing the week 11 faecal egg count by the adult female worm burden. Diets were contrasted by means of a univariate ANOVA on logtransformed fecundity data.

Mean transit time (MTT) of solids in the caecum and colon were estimated as: 


$$
\operatorname{MTT}(\mathrm{h})=\frac{\text { Mass of marker in segment }(\mathrm{mg})}{\text { Daily intake of marker }(\mathrm{mg})} * 24 \mathrm{~h}
$$

The content of polysaccharides residues was calculated as anhydrosugars and all apparent digestibilities were calculated relative to $\mathrm{Cr}_{2} \mathrm{O}_{3}$ content:

$$
\text { Digestibility of } X(s)=\left[1-\frac{\mathrm{Cr}_{2} \mathrm{O}_{3}(\mathrm{~d})}{\mathrm{Cr}_{2} \mathrm{O}_{3}(\mathrm{~s})} \times \mathrm{X}_{(\mathrm{s})}\right] \times 100
$$

where $\mathrm{X}(\mathrm{d})$ and $\mathrm{X}(\mathrm{s})$ are the concentrations of specific nutrients in the diet $d$ and in digesta materials from the segments of the gastrointestinal tract ( $s \in\{\mathrm{I}, \mathrm{Ce}$, Co1, Co2, Co3, Co4-5\}). When calculating starch digestibility it was assumed that free glucose in digesta materials derived from starch.

Profiles of the concentrations of nutrients and digestibilities over the sections SI4, Ce, Co1, Co2, Co3, and Co4 were analyzed by the ante-dependence model as described by Kenward (1987). Data from section Co5 were removed since this section was unobserved for most pigs. Let $\mathrm{Y}_{\mathrm{ij} k}$ be the response of pig $i$ in section $j$ fed with diet $k$. We assume that the responses are normally distributed with the following (co) variance:

$$
\mathrm{V}\left(\mathrm{Y}_{\mathrm{ijk}}\right)=\sigma_{\hat{j}}^{2}, \operatorname{Cov}\left(\mathrm{Y}_{\mathrm{ij} k}, \mathrm{Y}_{\mathrm{ij}, k}\right)=\sigma_{\hat{j}} \sigma_{\mathrm{j}^{\prime}}, \prod_{\mathrm{l}=\mathrm{j}+1}^{\mathrm{j}^{\prime}} \rho_{1},
$$

where $\sigma_{\mathrm{i}}=\operatorname{corr}\left(\mathrm{Y}_{\mathrm{i}, \mathrm{ll}, k}, \mathrm{Y}_{\mathrm{il} k}\right)$.

Data from different pigs are assumed to be independent. This model acknowledges that the measurements within a pig are correlated and the different natures of the small intestine, caecum, and colon gives rise to variance heterogeneity. Furthermore the covariance structure results in responses from two sections which are conditionally independent given any intermediate sections are observed.

The ante-dependence model of Kenward (1987) is based on ANOVA. For a given section we consider the following model:

$$
Y_{i j k}=D_{j k}+a_{j k} y_{i, j l, k}+e_{i j k},
$$

where $\hat{\mathrm{e}}_{\mathrm{ijk}} \sim \mathrm{N}\left(0, \sigma_{\mathrm{c}}^{2}\right)$.

The regression parameter $\mathrm{a}_{\mathrm{jk}}$ represents the correlation between section $j$ and the preceding section $j-1$, and differences between diet effects, $D_{i k}$, represents differences between diets in changes in level from section $j-1$ to section $j$.

The relationship between worm burden and concentration of DF residues in individual segments of caecum and colon was analysed by a first order linear regression model and the relationship between the total worm burden and faecal epg, respectively, and the recovery of DF residues in Co4 by a second order regression model.

\section{RESULTS}

\section{COMPOSITION OF DIETS}

T The composition and the ingredients of the diets are shown in Table I. The increase in DF components was in the form of cellulose, insoluble NCP and Klason lignin reflecting the high levels of these components in the oat hull meal as this ingredient was substituted for barley flour and protein concentrate. As a consequence of increased level of DF, FUp decreased from $1.28 \mathrm{FUp} / \mathrm{kg} \mathrm{DM}$ (diet A) to $1.07 \mathrm{FUp} / \mathrm{kg} \mathrm{DM}$ (diet D), while digestible protein per FUp was constant.

\section{ANIMAL HEALTH AND PERFORMANCE}

All pigs had a normal appetite during the experiment and the rations of feed were completely consumed daily in all groups. None of the pigs had clinical signs of parasitism during the experiment. In all experimental groups the average weight of pigs increased gradually and the weight differences between groups were not significant $(P>0.05)$.

\section{FAECAL EGG COUNT}

Oesophagostomum dentatum eggs were detected in individual pigs at week 3 p.i. (Fig. 1), and were found in all pigs after the fourth week. A significant difference $(\mathrm{P}<0.01)$ in time post inoculation, the diet and time $\times$ diet effects was found between group D and the other diet groups.

\section{WORM BURDENS}

The O. dentatum worm burdens are shown in Figure 2. The average (standard deviation- SD) O. dentatum

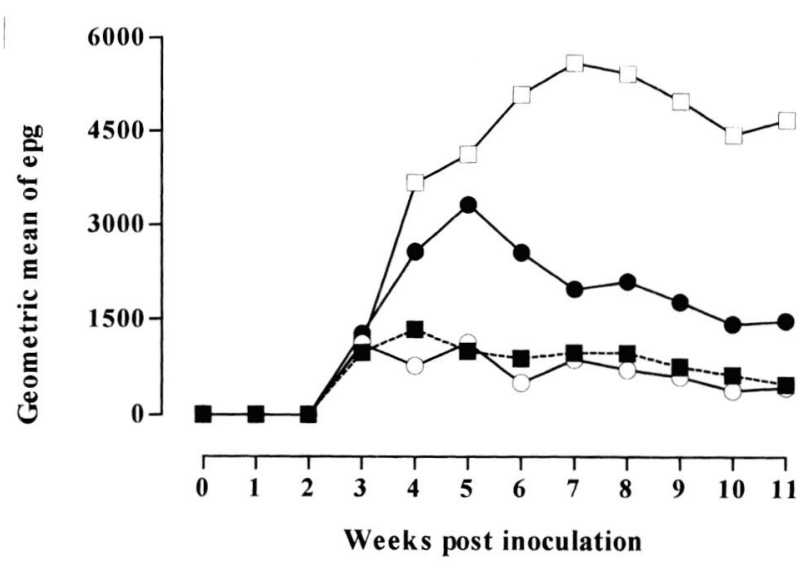

Fig. 1. - Geometric mean Oesophagostomum dentatum egg counts of pigs fed barley flour plus protein mixture (diet A-n), barley flour plus oat husk meal (1 part) plus protein mixture (diet B-O), barley flour plus oat husk meal (2 parts) plus protein mixture (diet $\mathrm{C}-\mathbf{0}$ ), barley flour plus oat husk meal (3 parts) plus protein mixture (diet D-ב). 


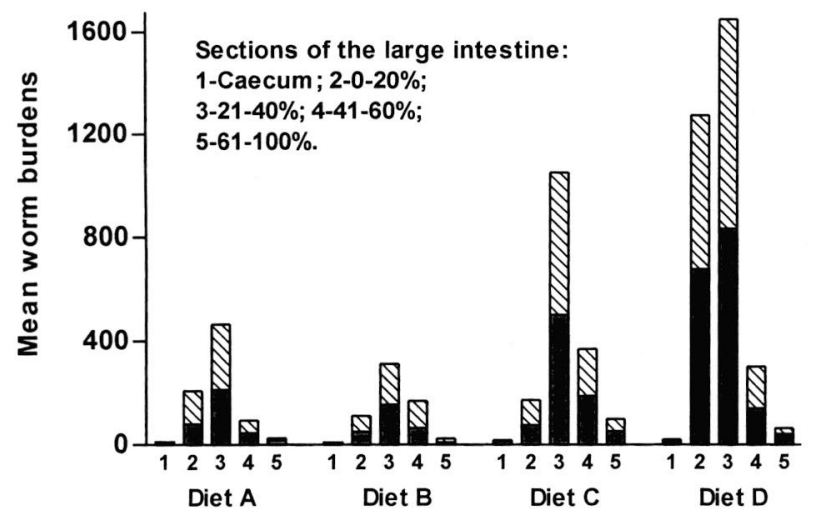

Mature females

Mature males

Fig. 2. - The mean location of Oesophagostomum dentatum worm burdens of pigs fed with by the four experimental diets.

worm burdens were 807 (643), 630 (499), 1714 (1872) and 3313 (2181) in groups A, B, C and D, respectively. The number of worms recovered was significantly higher $(\mathrm{P}<0.05)$ in group $\mathrm{D}$ than in groups $\mathrm{A}$ and $\mathrm{B}$. Total caecal (Ce) worm burden was not significantly affected by diet. In the proximal large intestine (Co1), pigs given diets with the highest content of oat hull meal (group D) had significantly higher $(\mathrm{P}<0.01)$ worm burdens compared to groups A, B and C. In $\mathrm{Co} 2$, pigs from group $\mathrm{D}$ showed statistically higher worm counts than in group B $(\mathrm{P}<0.05)$.

Average location of $O$. dentatum in the sections of the large intestine is shown in Figure 2. Average (SD) O. dentatum location for diets A, B, C and D was: 2.9 (0.3), $3.4(0.5), 3.0(0.4)$ and $2.7(0.2)$, respectively. All O. dentatum worms recovered were adults and in all diet groups there was an equal distribution of females and males.

\section{WORM FECUNDITY}

Back-transformed average $O$. dentatum fecundity (epg per adult female worm (SD)) was 1.7 (1.2), 1.9 (1.8), 3.1 (2.5), and 5.3 (3.3) in the four experimental groups, respectively. Diet $D$ was found to have a significant effect on fecundity compared to diet A $(\mathrm{P}<0.05)$.

\section{DigESTIBILITY OF POLYSACCHARIDES AND ORGANIC MATTER}

Degradation of nutrients in the large intestine is shown in Table III and digestibility of NSP at ileum and in sections of caecum and colon in Figure 3. Degradation of organic matter in large intestine was $888 \mathrm{~g} / \mathrm{d}$ with diet $\mathrm{A}, 763 \mathrm{~g} / \mathrm{d}$ with $\operatorname{diet} \mathrm{D}, 588 \mathrm{~g} / \mathrm{d}$ with $\operatorname{diet} \mathrm{B}$, and $513 \mathrm{~g} / \mathrm{d}$ with diet $\mathrm{C}(\mathrm{P}<0.04)$. Starch degrada-

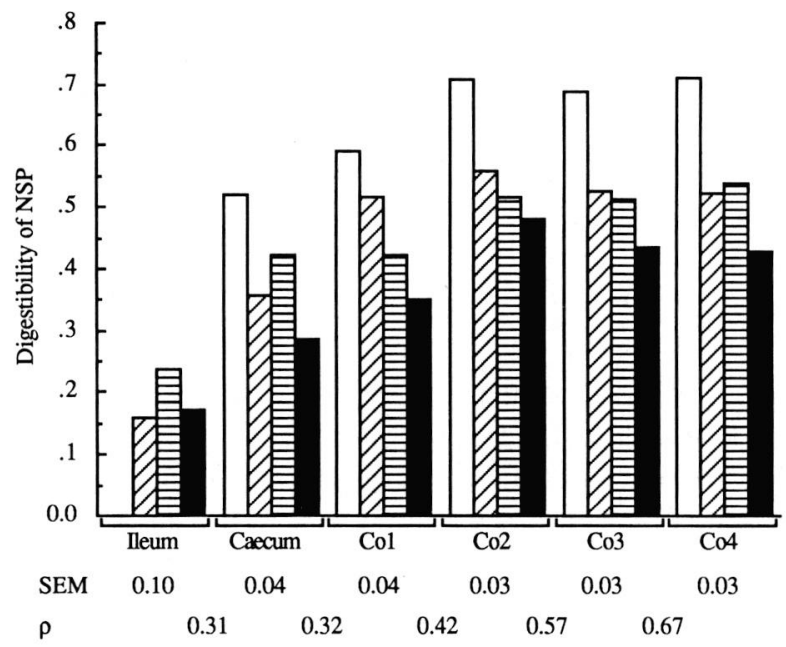

Fig. 3. - Digestibility of non-starch polysaccharides in ileum, caecum and colon 1-4 when feeding diet A ( $\square$ ), B ( $(2)$ ), C (圆) and D (ם). $P$-values for difference between diet profiles is: 0.00006 . Marginal diet effects and conditional diet effects are shown in Table II.

\begin{tabular}{|c|c|c|c|c|c|c|}
\hline & \multicolumn{6}{|c|}{ Section } \\
\hline & Ileum & Caecum & Colon 1 & Colon 2 & Colon 3 & Colon 4 \\
\hline \multicolumn{7}{|l|}{ Concentrations } \\
\hline Chromic oxide & $\mathrm{ns} / \mathrm{ns}$ & $* / *$ & $* * * /$ ns & $* * /$ ns & $* * * / n s$ & ${ }^{* * *} / \mathrm{ns}$ \\
\hline Lignin & $\mathrm{ns} / \mathrm{ns}$ & $* * * / * * *$ & $* * * / n s$ & ${ }^{* * *} / \mathrm{ns}$ & $* * * / n s$ & ${ }^{* * *} / \mathrm{ns}$ \\
\hline NSP & $\mathrm{ns} / \mathrm{ns}$ & $* * * / * * *$ & $* * * / * * *$ & ${ }^{* * *} / \mathrm{ns}$ & $* * * / \mathrm{ns}$ & $* * * / \mathrm{ns}$ \\
\hline SCFA & $\mathrm{ns} / \mathrm{ns}$ & $* / *$ & $* * / *$ & $* / \mathrm{ns}$ & $* / \mathrm{ns}$ & $\mathrm{ns} / \mathrm{ns}$ \\
\hline $\mathrm{pH}$ & $\mathrm{ns} / \mathrm{ns}$ & $\mathrm{ns} / \mathrm{ns}$ & $\mathrm{ns} / \mathrm{ns}$ & $\mathrm{ns} / \mathrm{ns}$ & $\mathrm{ns} / \mathrm{ns}$ & $\mathrm{ns} / \mathrm{ns}$ \\
\hline \multicolumn{7}{|l|}{ Digestibility } \\
\hline NSP & $\mathrm{ns} / \mathrm{ns}$ & $* * / * *$ & $* * * * * *$ & $* * * / * *$ & ${ }^{* * *} / \mathrm{ns}$ & $* * * / *$ \\
\hline
\end{tabular}

NSP, non-starch polysaccharides; SCFA, short-chain fatty acids; ns, non-significant; ${ }^{*} P<0.05 ;{ }^{* *} P<0.01 ;{ }^{* * *} P<0.001$.

Table II. - Marginal diet effects expressed as the difference between diets on a given level and conditional diet effects expressed as the difference between diets changes from the last section. 


\begin{tabular}{|c|c|c|c|c|c|c|}
\hline & \multicolumn{4}{|c|}{ Diet } & \multirow[b]{2}{*}{ SEM } & \multirow[b]{2}{*}{$P$-value diet } \\
\hline & $\mathbf{A}$ & B & C & D & & \\
\hline Organic matter & $888^{b}$ & $588^{\mathrm{ab}}$ & $513^{\mathrm{b}}$ & $763^{\mathrm{ab}}$ & 93 & 0.04 \\
\hline Carbohydrates & 268 & 204 & 153 & 168 & 42 & 0.26 \\
\hline Starch & $41^{\mathrm{a}}$ & $25^{\mathrm{ab}}$ & $13^{\mathrm{b}}$ & $34^{\mathrm{ab}}$ & 7 & 0.05 \\
\hline \multicolumn{7}{|l|}{ NSP: } \\
\hline Cellulose & 48 & 27 & 19 & 4 & 18 & 0.39 \\
\hline NCP & 179 & 149 & 121 & 131 & 25 & 0.37 \\
\hline Total NSP & 227 & 179 & 140 & 134 & 42 & 0.39 \\
\hline \multicolumn{7}{|l|}{ DF residues $(g)$} \\
\hline Caecum & $10.7^{\mathrm{b}}$ & $16.9^{\mathrm{a}}$ & $17.8^{\mathrm{a}}$ & $19.3^{\mathrm{a}}$ & 1.4 & 0.001 \\
\hline Colon & $64.3^{\mathrm{b}}$ & $80.3^{\mathrm{ab}}$ & $100.4^{\mathrm{a}}$ & $101.9^{\mathrm{a}}$ & 7.8 & 0.0053 \\
\hline Total large intestine & $75.0^{\mathrm{b}}$ & $97.3^{\mathrm{ab}}$ & $118.2^{\mathrm{a}}$ & $121.2^{\mathrm{a}}$ & 8.5 & 0.025 \\
\hline \multicolumn{7}{|l|}{ Mean transit time } \\
\hline Caecum & 1.4 & 1.3 & 1.3 & 1.0 & 0.1 & 0.08 \\
\hline Colon & $11.7^{\mathrm{a}}$ & $8.0^{\mathrm{b}}$ & $8.0^{\mathrm{b}}$ & $6.1^{\mathrm{b}}$ & 0.8 & 0.0006 \\
\hline Total large intestine & $13.1^{\mathrm{a}}$ & $9.3^{\mathrm{b}}$ & $9.3^{b}$ & $7.1^{\mathrm{b}}$ & 0.9 & 0.0008 \\
\hline
\end{tabular}

Values are means of seven pigs. Group means in the same row followed by different letters are significantly different $(P<0.05)$. NSP, non starch polysaccharides; NCP, non-cellulosic polysaccharides; DF, dietary fibre; SEM, standard error of means.

Table III. - Degradation of nutrients (gram/day) in the large intestine, dietary fibre residues (gram) and mean transit time (hour) in caecum and colon.

tion followed a similar pattern as organic matter, while there was no significant difference between diets in degradation of NSP, cellulose or NCP. Decrease in degradation of total NSP and its components, however, was significantly correlated with intake of dietary DF $(\mathrm{r}=-0.962, \mathrm{P}<0.04)$.

Digestibility of NSP at ileum varied between 0.00 and 0.24 (Fig. 3). The digestibility of diet $\mathrm{A}$ increased to 0.52 in caecum, to 0.59 in Co1 and to approximately 0.70 in Co2-Co4. Caecal digestibility of NSP for diets $\mathrm{B}, \mathrm{C}$ and $\mathrm{D}$ was approximately between 0.28 and 0.42 , and was not significantly different between those three diets but lower than diet A $(\mathrm{P}<0.05)$ (Table II). Distal to the caecum digestibility of NSP ranked diet $\mathrm{B}>\operatorname{diet} \mathrm{C}>$ diet $\mathrm{D}$; the difference being most significant in Co4 where digestibility was: diet D 0.43 , diet C 0.54 , and diet B 0.62 .

\section{AMOUNT OF DIETARY FIBRE RESIDUES \\ IN THE LARGE INTESTINE}

\section{AND THE MEAN TRANSIT TIME}

There was an increase in amount of DF residues in the large intestine in response to the DF intake (Table III). With diet A $75 \mathrm{~g}$ was recovered in the large intestine increasing gradually to $121 \mathrm{~g}$ with diet D. MTT varied between 1.0 and 1.4 hours in the caecum $(\mathrm{P}>$ 0.05 ) and between 7.1 hours (diet D) and 13.1 hours (diet A) in the colon $(\mathrm{P}<0.0006)$.

\section{ACCUMULATION OF INSOLUBLE MARKER, LIGNIN AND NSP RESIDUES IN THE GASTROINTESTINAL TRACT}

The average concentration of the indigestible marker (chromic oxide) and lignin in ileal digesta across all diets was approximately $4 \mathrm{~g} / \mathrm{kg} \mathrm{DM}$ and $60 \mathrm{~g} / \mathrm{kgDM}$, respectively with no significant difference between the four diets. With both parametres, however, there was no significant dietary effect in caecum and all segments of colon (Table II), with the most significant changes observed from terminal ileum to proximal colon (Co 1). The concentrationof NSP was $221 \mathrm{~g} / \mathrm{kg}$ DM in ileal digesta when feeding diet A and 266286 DM when feeding the other three diets. With diet A concentration of NSP did not change from ileum and throughout caecum and colon (average concentration $228 \mathrm{~g} / \mathrm{kg} \mathrm{DM}$ ), while with the other three diets the concentration in caecum and colon followed the dietary levels, the average concentrations being 301, 337 and $376 \mathrm{~g} / \mathrm{kg}$ DM for diet B, C and D, respectively.

\section{ORGANIC ACIDS AND PH}

Concentrations of SCFA and LA in ileal digesta were $28-57 \mathrm{mmol} / \mathrm{kg}$ digesta (Fig. 4) and $50-110 \mathrm{mmol} / \mathrm{kg}$ digesta, respectively (LA data not shown). LA disappeared almost completely in caecum and colon, and there was a significant increase in the concentration 

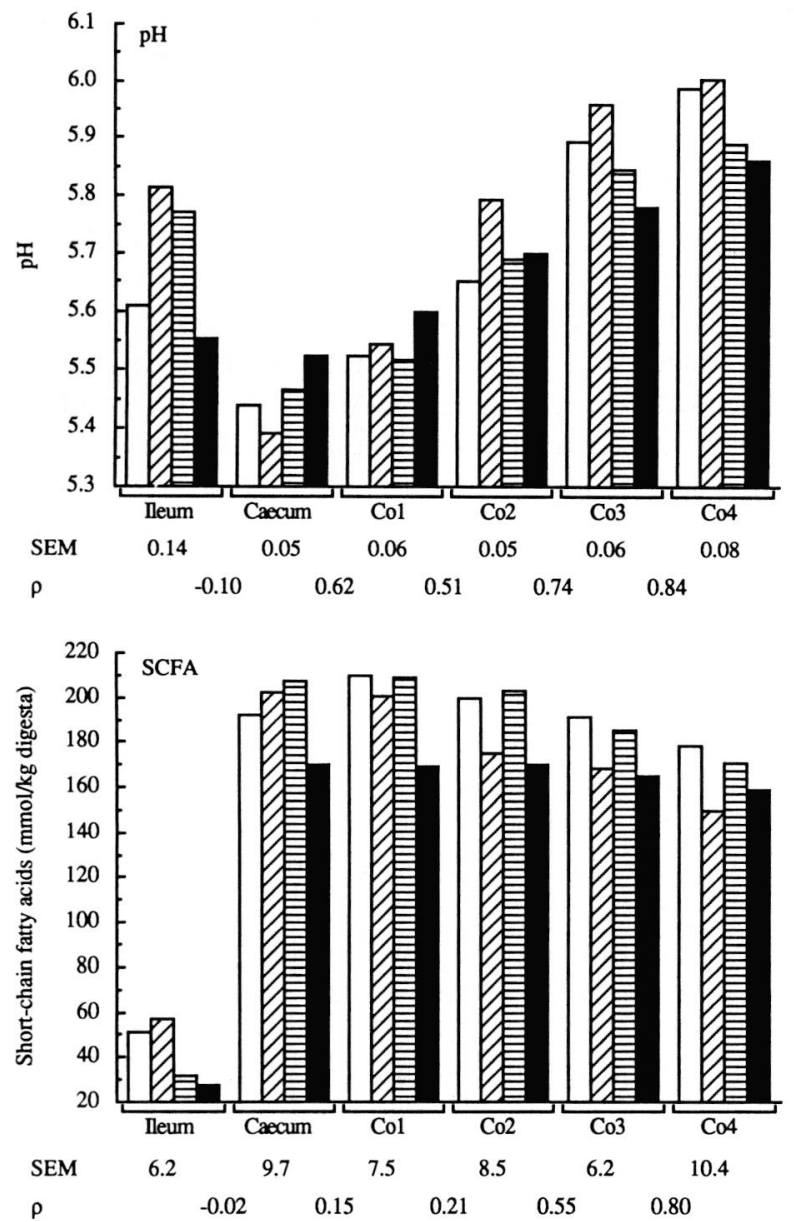

Fig. 4. $-\mathrm{pH}$ and the concentration ( $\mathrm{mmol} / \mathrm{kg}$ digesta) of short-chain fatty acids in ileum, caecum and colon 1-4 when feeding diet A ( $\square$ ), $\mathrm{B}(\square), \mathrm{C}($ 园) and $\mathrm{D}(\boldsymbol{\square}) . P$-values for difference between diet profiles for $\mathrm{pH}$ is: 0.72 and for short-chain fatty acids is: 0.011. Marginal effects and conditional diet effects are shown in Table II.

of SCFA to $170-210 \mathrm{mmol} / \mathrm{kg}$ digesta in caecum. This level was kept in $\mathrm{Co} 1$ and $\mathrm{Co} 2$ but decreased slightly to $150-170 \mathrm{mmol} / \mathrm{kg}$ digesta in Co4. Acetate accounted 90-97 per cent of the SCFA in ileal digestion. In caecum and colon the following molar proportions were found; acetate 55-60 per cent; propionate 21-33 per cent butyrate 11-14 per cent and branched-chain fatty acids (BCFA) 0.1-1.3 per cent.

The $\mathrm{pH}$ in ileal digesta was 5.5-5.8 and in the caecum 5.4-5.5 (Fig. 5). Distal to the caecum there was a gradual increase in $\mathrm{pH}$ approaching 5.9-6.0 in Co4.

\section{WORM BURDEN, FAECAL EPG COUNTS AND DIETARY CONSTITUENTS}

Total worm number within the individual sections of the large intestine was poorly correlated with concentration of dietary residues. The highest correlation was found between total worm number and concentration
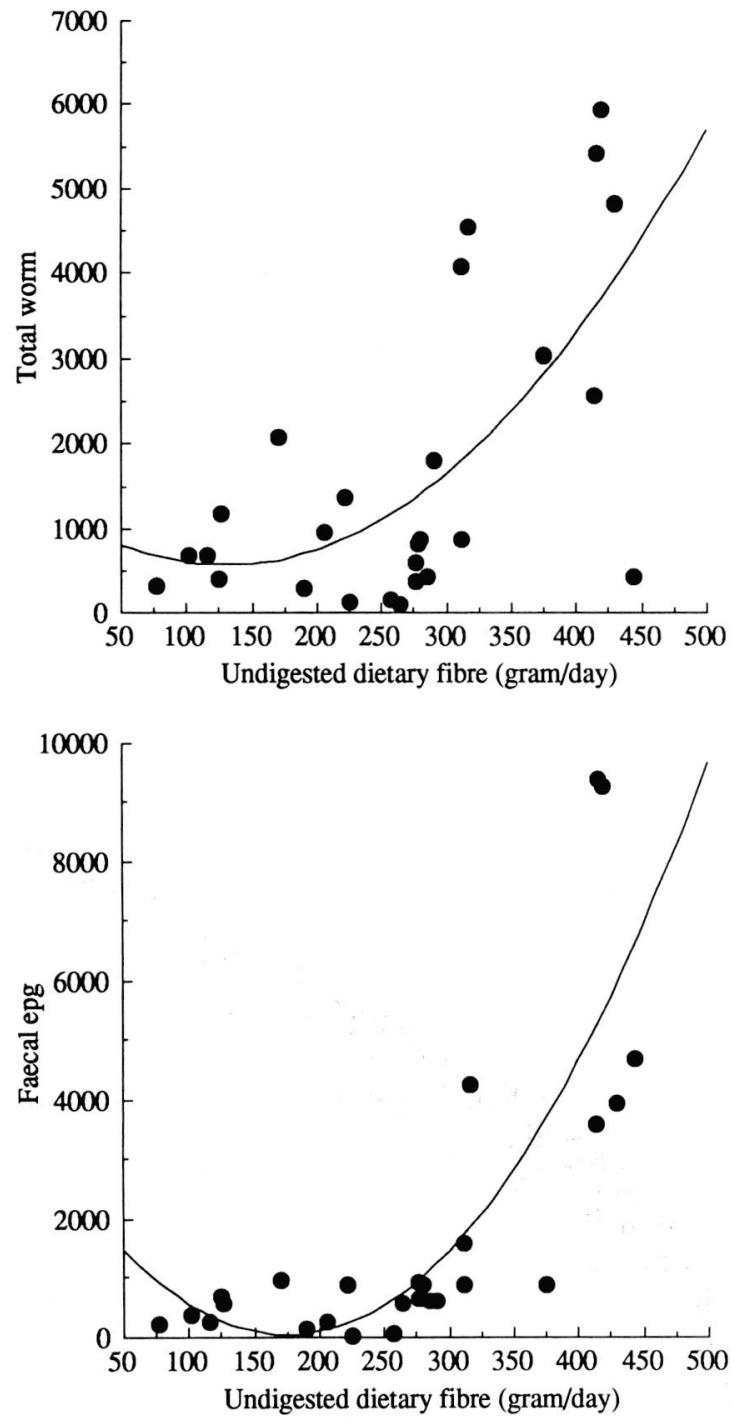

Fig. 5. - Correlation between the amount of undigested dietary fibre (UDF) recovered in colon 4 and total worm burden and faecal epg. The relationship can be expressed as: Total worm burden $=1,199$ - $9.7 \times \mathrm{UDF}+0.04 \mathrm{UDF}^{2}, \mathrm{R}^{2}=0,43(P<0.001)$ and Faecal epg $=2,864-32 \times \mathrm{UDF}+0.09 \mathrm{UDF}^{2}, \mathrm{R}^{2}=0.64(P<0.0008)$.

of DF in section Co1. Total worm burden and faecal epg counts, however, were curvilinearly related to recovery of DF residues at Co4 (Fig. 5).

\section{DISCUSSION}

The results of this experiment confirm previous studies that diets with high levels of insoluble DF and consequent low digestibility favourably influence survival, growth and fecundity of gastrointestinal parasites. The diet with the highest level of insoluble $\mathrm{DF}$, diet $\mathrm{D}$, led to a significant increase in the O.dentatum faecal egg excretion, worm number 
and fecundity. In contrast, when the host was fed diets with lower levels of DF (diet A and B), O. dentatum was located more distally in the large intestine, and fecundity was found to be depressed from week 4 p.i. Since level of $O$. dentatum eggs was related to fecundity in all experimental groups it is likely that the negative influence of the diet on the establishment of $O$. dentatum has started in the pre-patent period before the initial egg excretion. The result from this study is in agreement with our earlier findings (Petkevičius et al., 1995, 1997a; Bjørn et al., 1996), that diets with high levels of insoluble NSP and lignin significantly increased $O$. dentatum worm establishment and fecundity.

This study was designed to investigate the effect of the dietary level of insoluble DF on metabolism in the large intestine and establishment and persistence of $O$. dentatum, while keeping the level of essential nutrients (digestible protein) constant. High dietary DF content had a significant impact on physiology of the large intestine as seen in reduced MTT, increased concentrations of DF residues, amounts of DF in the large intestine and changed $\mathrm{pH}$ and SCFA, when compared to lower dietary DF content. It is also likely that other luminal parameters (e. g., pressure of carbon dioxide and bile acids), which have been found to interfere with the development and adaption of gastrointestinal parasites (Hawdon \& Schad, 1991), were affected by dietary composition. These data suggest a direct relationship between environment in the lumen of the large intestine and establishment of parasites. However, it should be noted that the relationship between the faecal egg epg and total worm burden and dietary level of insoluble DF is not straight forward. As found in present study, a threshold of undigested DF ( 300 gram/day) needs to be reached before the establishment and fecundity of $O$. dentatum is significantly affected.

The caecum and proximal colon are the principal sites for carbohydrate fermentation in the large intestine (e.g. Bach Knudsen et al., 1991, 1993). In these segments the fermentation is consequently active with a high production of SCFA and an acidic $\mathrm{pH}$. As the digesta moves aborally in the large intestine the residues are depleted for the most readily fermentable nutrients, the concentration of SCFA starts to decline and the $\mathrm{pH}$ to rise. This is also found in the present study where the plateau level for digestibility of NSP and the concentration of insoluble marker was reached in $\mathrm{CO} 2$ with little further increase beyond that point. In this discussion it is noticeable that with all the diets there was consistently a low level of worms in the caecum and for all but diet D in Co1 while the highest worm burden with all diets was found in $\mathrm{CO} 2$. The reason for this variation in location could potentially be that the enviroment in the middle colon is less variable than in caecum and proximal colon. For a parasite with a predominant anaerobic metabolism i.e. O. dentatum (Bolla, 1987) this may be an advantage as the parasite needs to adapt less to changes in the luminal environment.

The effect of diet on the establishment of $O$. dentatum may be indirect as well. The dietary composition in particular the type and level of DF, is now established as a major contributor to the colonic function and bowel habit in humans as well as other non-ruminant species (e. g. Macfarlane \& Cummings, 1991). Increased levels of DF will inevitably affect metabolism in the large intestine influencing the morphology and proliferation of epithelial cells and mucus formation. Since mucus acts as a barrier against chemical and mechanical damage to the underlying epithelial cells, the balance between synthesis, secretion and erosion is important (Allen, 1981; Quigley \& Kelly, 1995). An increased intake of DF is generally considered positive for the health of the large intestine because it raises the ratio of dietary carbohydrates over endogenous substances (Quigley \& Kelly, 1995). These conditions are considered positive for the ability of the host to maintain the mucosal layer. However, the high level of highly resistant DF, as used in this study, may have resulted in increased mechanical stress of the mucus layer thereby potentially damaging the underlying epithelial cells (Allen, 1981). The consequence would be that the whole luminal enviroment is more susceptible to infection with $O$. dentatum.

Parasite survival, when first established in the host, depends on nutrients that can be obtained from the host (Crompton, 1991). When nutrients are not present in adequate quantities because of deficient dietary intake, gastrointestinal parasites are in an abnormal environment, in which they are usually unable to develop and survive (Solomons \& Scott, 1994). Fasting of pigs for ten days, which changed the environment of the intestinal lumen, decreased numbers and fecundity of A. suum and Oesophagostomum spp., and worms were found in more distal locations of the gastrointestinal tract compared to control (Petkevičius et al., 1997b). The lack of carbohydrates available for fermentation in the large intestine can be one of the reasons for marked reduction in establishment of Oesophagostomum spp., nodular worms with predominantly anaerobic metabolism (Bolla, 1987). These findings are further supported by results demonstrating that dietary carbohydrates are necessary to $O$. dentatum for either fecundity or maturation, or possibly both (Herbert et al., 1969).

In conclusion, this experiment demonstrated that diets formulated with increasing levels of insoluble DF but with constant levels of digestible protein per FUp significantly modified establishment and persistence of 
O. dentatum. This study substantiates previous findings (Petkevičius et al., 1995, 1997a) and provides additional support for the hypothesis that a diet with a high level of lignin and insoluble NSP provides favourable conditions for establishment and persistence of O. dentatum in the large intestine of pigs.

\section{ACKNOWLEDGEMENTS}

The study was supported by the Danish National Research Foundation.

\section{REFERENCES}

ALLEN A. Structure and function of gastrointestinal mucus, in: Physiology of the gastrointestinal tract. Johnson, L.R. (eds), Raven Press Ltd., New York, 1981, 617-639.

Association of Official Analytical Chemists. Official methods of analysis. Washington D.C., Association of Official Analytical Chemists, 1975

Bach Knudsen K.E. Carbohydrate and lignin contents of plant materials used in animal feeding. Animal Feed Science and Technology, 1998 (in press).

Bach Knudsen K.E., Jensen B.B., Andersen J.O. \& Hansen I. Gastrointestinal implications of wheat and oat fractions. 2. Microbial activity in the gastrointestinal tract. British Jour nal of Nutrition, 1991, 65, 233-248.

Bach KNudsen K.E., Jensen B.B. \& Hansen I. Digestion of polysaccharides and other major components in the small and large intestine of pigs fed diets consisting of oat fractions rich in $\beta$-D-glucan. British Journal of Nutrition, 1993, 70, 537-556.

BJøRn H., RoEpstorfF A. \& NANSEN P. A possible influence of diet composition on the establishment of nematodes in the pig. Veterinary Parasitology, 1996, 63, 167-171.

Boisen S. \& Fernàndez J.A. Prediction of the total tract digestibility of energy in feedstuffs and pig diets by in vitro analyses. Animal Feed Science and Technology, 1998 (in press).

Bolla R.I. Nematodes as Model Systems for Nutritional Studies, in: Vistas in Nematodology: A commemoration of the twenty-fifth anniversary of the Society of Nematodologists. Maryland, 1987, 56, 424-432.

Crompton D.W.T. Nutritional interactions between host and parasites, in: Parasite-host associations. Coexistence or conflict? Toft C.A., Aeschlimann A. \& Bolis L. (eds), Oxford University Press, Oxford, 1991, 228-257.

Englyst H.N., Wiggins H.S. \& Cummings J.H. Determination of non-starch polysaccharides in plant foods by gas-liquid chromatography of constituent sugars as alditol acetates. Analyst, 1982, 107, 307-318.

Goodey T. Some stages in the development of Oesophagostomum dentatum from the pig. Journal of Helminthology, 1926, 4, 191-198.
Hawdon J.M. \& Schad G.A. Developmental adaptations in nematode, in: Parasite-host associations. Coexistence or conflict? Toft C.A., Aeschlimann A. \& Bolis L. (eds), Oxford University Press, Oxford, 1991, 274-298.

Herbert I.V., Lean I.J. \& Nickson E.W. Dietary factors and the production of Oesophagostomum spp. ova in breeding pigs. Veterinary Record, 1969, 84, 569-570.

Johansen H.N., Bach Knudsen K.E., Wood P.J. \& Fulcher R.G. Physico-chemical properties and the digestibility of polysaccharides from oats in the gastrointestinal tract of pigs. Journal of Food and Agriculture, 1997, 73, 81-92.

Just A. The digestibility of amino acids from different balance feed rations as related to the digestibility of nitrogen in growing pigs. Acta Agriculture Scandinavia, 1971, 21, 189192.

Just A. Feed evaluation in pigs. World Review of Animal Production, 1975, 11, 18-30.

KenWARD M. G. A method for comparing profiles of repeated measurements. Applied Statistics, 1987, 36, 296-308.

Macfarlane G.T. \& Cummings J.H. The colonic flora, fermentation, and the large bowel digestive function, in: The large intestine: physiology, pathology, and disease. Philips S.F., Pemberton J.H. \& Short R.G.(eds), Raven Press Ltd, New York, 1991, 51-92.

NESHEIM M.C. Some experimental approaches to the study of nutrition and parasitic infection. Federation-Proceedings, 1984, 43, 235-238.

Petkevičius S., Bach Knudsen K.E., Nansen P., Roepstorff A., SkJøth F. \& JENSEN K. The impact of diets varying in carbohydrates resistant to endogenous enzymes and lignin on populations of Ascaris suum and Oesophagostomum dentatum in pigs. Parasitology, 1997a, 114, 555-568.

Petkevičius S., Bృørn H., Roepstorff A., Nansen P., Bach Knudsen K.E., Barnes E.H. \& Jensen K. The effect of two types of diet on populations of Ascaris suum and Oesophagostomum dentatum in experimentally infected pigs. Parasitology, 1995, 111, 395-402.

Petkevičius S., Nansen P. \& Stephenson L. The effect of fasting on Ascaris suum and Oesophagostomum spp. in growing pigs. International Journal for Parasitology, 1997b, 27, 431-437.

QUIGLEY M.E. \& KelLy S.M. Structure, function, and metabolism of host mucus glycoproteins, in: Human colonic bacteria: Role in nutrition, physiology, and pathology. Gibson G.R. \& Macfarlane G.T. (eds), CRC Press, Boca Raton, 1995, 175-199.

Richardson A.J., Calder A.G., Stewart C.S. \& Smith A. Simultaneous determination of volatile and non-volatile acidic fermentation products of anaerobes by capillary gas chromatography. Letters in Applied Microbiology, 1989, 9, 5-8.

Roepstorff A., Bృørn H. \& NANSEn P. Resistance of Oesophagostomum spp. in pigs to pyrantel citrate. Veterinary Parasitology, 1987, 24, 229-239.

SChÜRCH A.F., LOYD L.E. \& CRAMPTON E.W. The use of chromic oxide as an index for determination the digestibility of a diet. Journal of Nutrition, 1950, 50, 629-636. 
Slotved H.C., Barnes E.H., Bjørn H., Christensen C.M., ERiKsen L., Roepstorff A. \& NANSEn P. Recovery of Oesophagostomum dentatum from pigs by isolation of parasites migrating from large intestinal contents embedded in agar-gel. Veterinary Parasitology, 1996, 63, 237-245.

Solomons N.W. \& ScotT M.E. Nutritional status of host populations influences parasitic infections, in: Parasitic and infectious diseases. Epidemiology and ecology. Scott M.E. \& Smith G. (eds), Academic Press Inc, San Diego, USA, 1994, 101-114

STOLDT W. Vorschlag zur Vereinheitlinchung der Fettbestimmung in Lebensmitteln. Fette, Seifen, Anstrichmittel, 1952, 54, 206-207.

Theander O. \& Åman P. Studies on dietary fibre. 1. Analysis and chemical characterization of water-soluble and waterinsoluble dietary fibres. Swedish Journal of Agricultural Research, 1979, 9, 97-106.

Theander O. \& Westerlund E.A. Studies on dietary fiber. 3. Improved procedures for analysis of dietary fiber. Journal of Agricultural and Food Chemistry, 1986, 34, 330336.

Von Brand T. Nutrition, in: Biochemistry and physiology of endoparasites. Elsevier/North-Holland Biomedical Press, Amsterdam, 1979, 28-79.

Reçu le 19 mars 1998 Accepté le 15 octobre 1998 